\title{
第25回紙パフフ計装技術発表会・特別講演 I
}

\section{列車の自動運転制御 \\ 一エキスパートシステムの自動列車運転装置への適用}

三菱電機株式会社 系統変電・交通システム事業所 満 川 昌 彦

\section{The Automatic Train Operation Equipment with Expert System}

TDTSC, Mitsubishi Electric Corporation

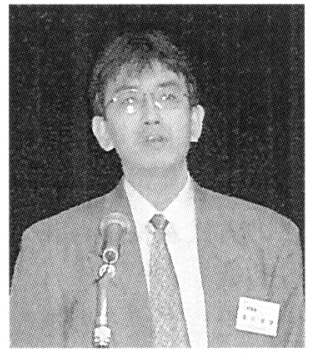

Recently, the subway which required one-man operation has come to be constructed. In the Automatic Train Operation system, it is important to operate the train accurately. But the improvement of riding comfort and the energy saving are attached to importance compared with before.

To achieve more highly developed operation, and to satisfy such a demand, we apply the expert system to the Automatic Train Operation system. In this discourse, Automatic train Operation Equipment with Expert system is described.

分類：V，計装・制御システム一般， Y 1 基礎科学一般

\section{1.はじめに}

近年，首都圈地下鉄路線をはじめ，新規に建設され る鉄道路線では，ワンマン運転を前提とした路線が増 えつつある。ワンマン運転の路線では, 安全の確保, 乗務員への負担をできるだけ少なくする工大が必要と なる。その中で, 列車の連転の負担を軽減するために 自動運転装置が導入されるケースが多い。

もともと, 自動運転装置は, 正確な列車の運転にの みに重点が扔かれてきたが，最近はその上に，“良い 乗り心地”や省エネルギー等を加味した，より高度な 運転方式の先現が重要視されてきた。こうした要求を 満足し，しかも高い信頼性を持ったシステムとして， “エキスパートシステム”が自動運転装置に組み达ま れ実用化されている。
以下，本文ではそのエキスパートシステムを適用し た，列車の白動運転制御に関わる内容を紹介古る。

\section{2. 自動運転装置の導入の流れ}

我が国で本格的に自動運転システムが採用されたの は，1981年に神戸の人工島であるポートアイランド へのアクセスラインとして建設された無人の新交通シ ステム（ポートライナー）であった。その後，大阪の 新交通システム（二ュートラム）など，主に無人シス テムの車両へと広がりをみせた。

近年，省エネ・省力化のニーズに伴い，新規に建設 される地下鉄路線などは，はじめから， ワンマン運転 を前提にしたシステムが計画され, その自動運転装置 として需要がふえつつある。

また，駅プラットホームでの乗客の車两への接触・ 


満川昌彦

ホームからの転落事故を防止する対策として，ホーム ドア (営団南北線で採用), ホーム可動柵（都営三田 線で採用）を設置する動きがある。ホームドアを開閉 するためには，一般的に停止目標の $\pm 50 \mathrm{~cm}$ の範用に 列車を確実に停車させる必要があり, 乗務員の高度な 運転技術が必要となり, 乗務員の負担が増大すること になる。この負担を軽減する目的にも自動運転装置が 採用される方向にある。

\section{3. 列車自動運転装置の分類}

\section{1 分類の定義}

列車自動運転装置は, その機能から大きく 3 つの夕 イプに分類できる。以下にその分類を示す。

(1) ATO (※1) 装置

出発の夕イミングで列車を起動させ駅間走行を行い, 定位置に自動的に停止させる機能を有する装置。新交 通システムの無人運転車両, 比較的新しく建設される 地下鉄ではこの方式が採用されている。

\section{(2)定速運転装置}

目標速度を設定して，その速度を維持するように列 車をコントロールする装置。一部のワンマンタイプの 新交通システムの車両に採用されている。

(3) TASC $(※ 2)$ 装置

出発から駅間走行は乗務員が行なうが，駅停止制御 のみ自動的に行なう装置。既設路線の運転支援装置と して採用されている。

\section{2 自動運転装置の採用例}

表 1 に，主な自動運転装置の採用例を示す。

\section{4. 列車の走行制御}

\section{1 自動運転対応車両の機器構成}

図 1 に ATO 装置対応車両の機器構成の一例を示す。 ATO 装置は, ATC (※3) 受信装置からの制限速度
信号に従い，力行 $(※ 4)$ ，ブレーキをコントロールす ることにより列車を走行・停止させる。列車の速度は， 車輪軸等に設置された速度発電機の発生周波数を基に 計算する。また，駅の所定停止位置に列車を停止させ るために，ATO 送受信装置から地点信号を受け，正 確な列車の位置を検出することができる。マスコン(※ 5）は，乗務員が手動運転するときの力行，ブレーキ の操作器である。

\subsection{ATO 装置による走行制御}

ATO 装置の基本機能である駅問の走行制御につい て述べる。ATO 装置は, 地上からの出発指令に従っ て走行制御を開始する。走行中は，常に ATC 装置に よる速度制限を受ける。この制限速度を越えて走行す ると，ATC装置によって自動的にプレーキがかかり， 制限速度以下まで列車の速度を低卜させる。したがっ て，ATO 装置はこの制限速度を越えない範讲で，で きるだけ速く円滑に走行させようとする。駅に近づく と減速を開始し, 定められた停止点に停止ささせ, 新交 通等のシステムでは，ホームドアが設けられており， 車両のドアとホームドアの位置がずれると開けること ができない。このため, 目標停止点に対しては正確に 停止させる必要がある。図 2 に一般的な駅間走行の例 を示す。

\section{5.エキスパートシステムによる列車の自動運転}

5.1 自動運転エキスパートシステム

は“自動運転エキスパートシステム”は，熟練運転士 のように柔軟かつ的確な判断による列車の運転を目指 すもので，運転制御に関する関するきめ細かな知識を 蓄えた“知識べ一ス”と，走行状態に心じて知識を選 択し，前向き推論によって制御指令を決定する “推論 エンジン”を中核として構成される。従来の自動運転 では困難であった特殊条件下での制御も，刘忘する知

表 1 自動運転装置の採用例

\begin{tabular}{|c|c|c|}
\hline タイプ & & 採 用 路 線 \\
\hline \multirow[t]{2}{*}{ ATO 装置 } & 無人 & $\begin{array}{l}\text { 横浜シーサイドライン, 神戸ポートライナー, 神う六甲1 } \\
\text { ライナー, 大阪ニュートラム, ゆりかもめ }\end{array}$ \\
\hline & 有人 & $\begin{array}{l}\text { 仙台市交南北線, 営団南北線, 都営三田線, 都営大江户 } \\
\text { 線, 埼玉高速線, 名古屋市交桜通線, 京都市交東西線, } \\
\text { 大阪市交鶴見緑地線, 神戸市交山手線, 神戸市父海岸:線, } \\
\text { 北神急行, 京阪電鉄東西線, 福岡市交空港線 }\end{array}$ \\
\hline 定速運転装置 & \multicolumn{2}{|c|}{ 桃花台新交通，広島高速交通 } \\
\hline TASC 装置 & \multicolumn{2}{|r|}{ 営団銀座線, 営団丸ノ内線, 東急目黒線, 東急池上:線 } \\
\hline
\end{tabular}




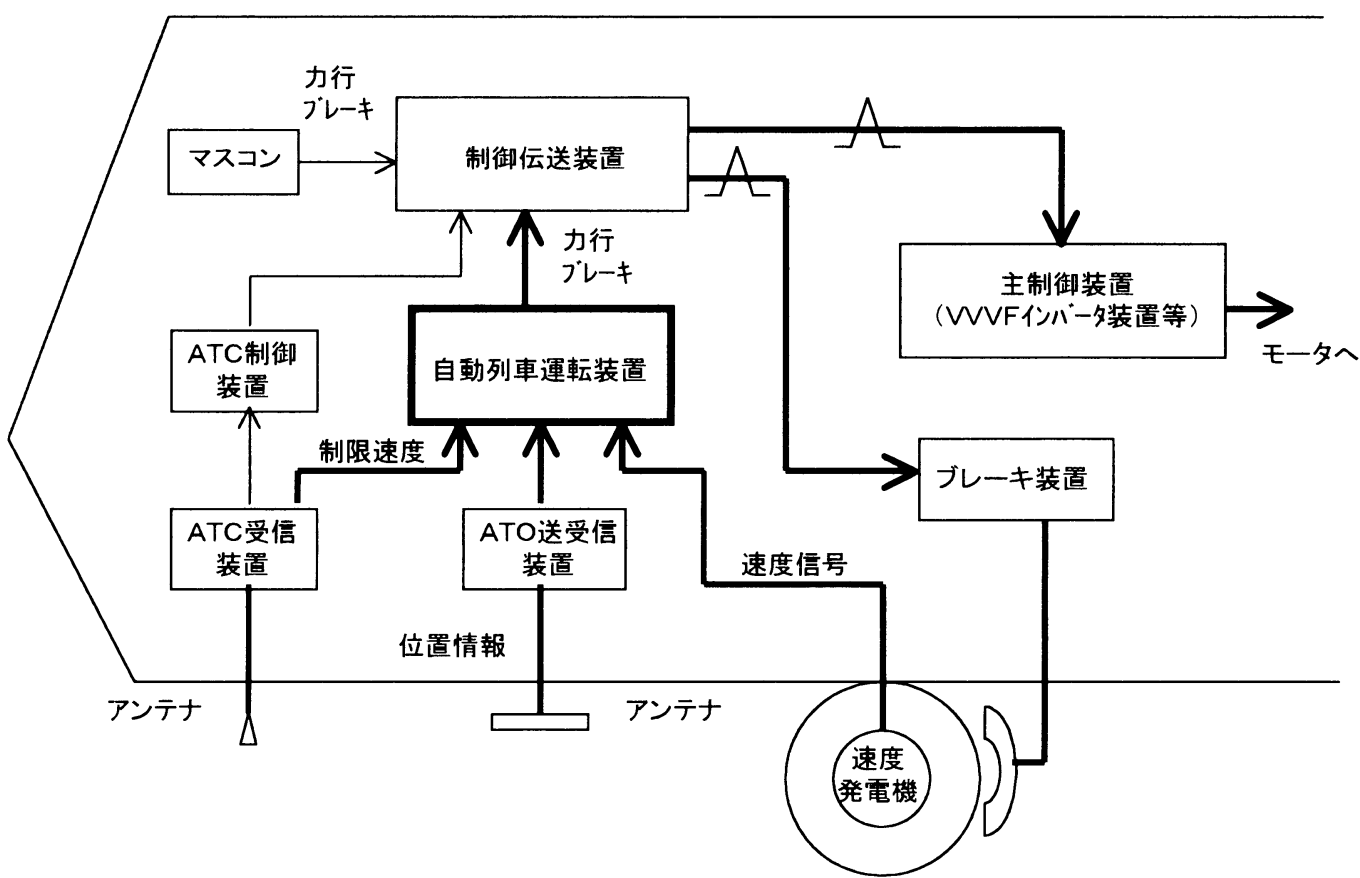

図 1 車両機器構成図

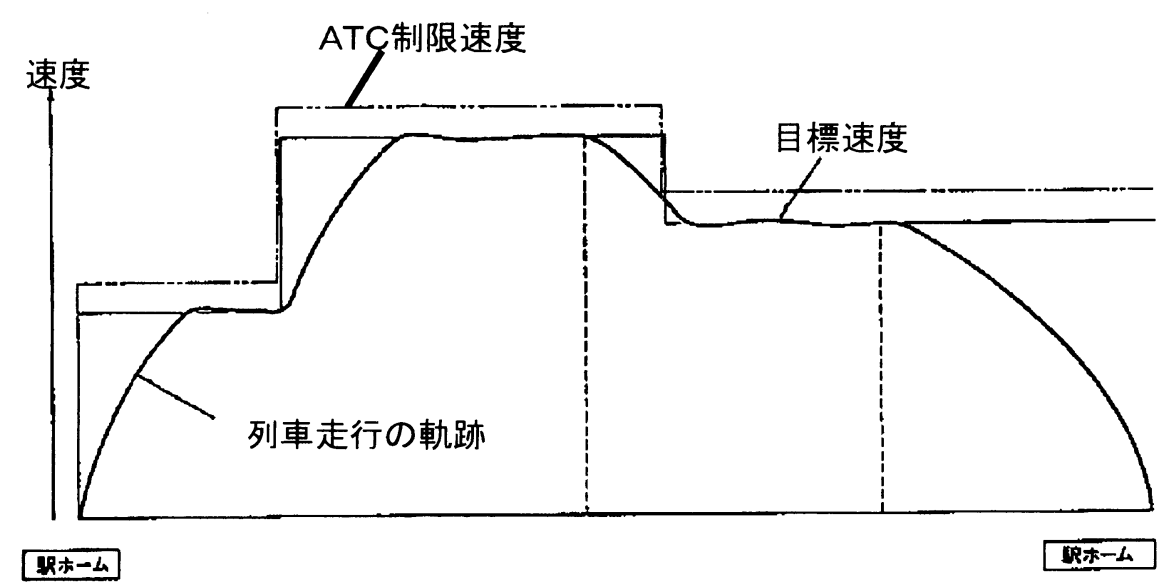

図 2 駅間走行パターン

識を追加することでうまく適合し，あらゆる局面にお いて最適な運転制御万式がが選択できる。このシステ ムは，神户新父通六中アイランド線向けATO 装置に 適用され，それ以降，弊社のATOで採用されている。 従来方式の列車に比べ，乗り心地の向上等に高い評価 を得ている。

\section{2 走行制御に適した制御方式}

列車の連転操作としては，マスコン力行ノッチある いはプレーキハンドルの扱いが主であり,さほと複雑
な操作ではない。しかしながら運転士は，運転状況に 応じて“的確に”操作することで, 列車をより速くし かも乗り心地良く運転している。熟練運転士ほど判断 が的確で無駄な動作が少ない。但し，操作は，“1秒 間に等間隔で 3 ノッチ進段させる”といった機械的正 確さは必要とされない。すなわち列車の運転では, 操 作の厳密さよりも状況判断能力がより重要な要素であ るといえる。また，自動制御をするにあたって，単一 の PID 制御 (比例・微分・積分制御) によって連度 
追随制御を行おうとすれぱ，過渡期にオーバーシュー トやアンダーシュートが発生してしまう（図 3)。こ れに対し，制御区間を「立ち上がり（加速）区間」, 「過渡区間」，「定速（速度維持）区間」に分割し，各 区間ごとに制御方式を変えれば比較的容易に円滑な追 随制御が実現できる（図 4)。すなわち，すべてのケ 一スに適用できる万能で複雑な制御方程式を解いて制 御していくよりも, 制御の条件を細分化し, その状況 に適合した単純な制御方式を選択していく方がうまく 制御できる。以上のことから, 列車の走行制御につい ていえば, 高度な制御演算能力よりも, 状況判断能力 に優れ, 状況に応じた操作が的確に選択できる方式が より有効であるといえる。

\section{3 エキスパートシステムによる走行制御}

「状況判断によって操作方法を選択していく」とい った人工知能的手法に適した方式として, ルールベー ス型のエキスパートシステムがある。運転士は，“速 度が出過ぎたのでノッチを少し戻そう。”といった判 断操作を行っている。ルールベース型システムでは, こうした判断操作を「IF（制御条件）THEN（制御手 順)」のように一般化されたルールの形で表すことが できる。“速度が出過ぎた”が制御条件に，“ノッチ を少し戻す”が制御手順に相当する。操作が運転士の 合理的な判断に基づく以上, すべての判断操作をルー ルの形で表現することができる。的確な判断を行なう ということは, 制御条件で示される状況認識にちょう ど適合するものが存在するということである。また，

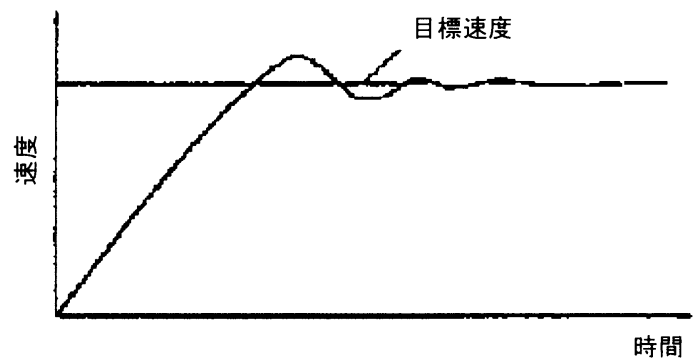

図 3 単一制御方式による応答

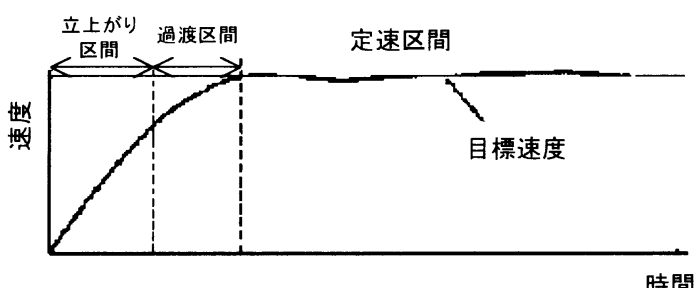

図 4 区間識別制御による応答
ルール次第で制御条件は十分にきめ細かく規定できる。 状況認識が細分化されれば制御すべき状況が限定でき, 制御手順をより単純化することができる。このシステ ムでは, すべての運転操作をルールの形で知識として 蓄えておき，この知識に基づいた状況判断によって列 車を運転していく。したがって, システムの成否はい かに有効な知識が獲得できるかにかかっている。

\section{6. 知識ベースの生成}

\section{1 走行モードの分類}

知識を作成する前提として，まず，走行制御の内容 を時系列的に分析し，走行状態に応じた幾つかの走行 モードに分割する。例えば，図 4 において，出発後の 立ち上がり区間を“加速モード”，過渡区間を“加速 緩和モード”，一定速度で走行する “定速モード”等 である。各走行モードが基本的な制御単位となり，知 識は走行モードごとにまとめて作成される。制御方式 をできるだけ単純化するために, 複雑な走行モードが あれば更に分割していく。

\section{2 知識のルール化}

走行モードごとに順次運転状洗を想定し，そこで行 われる判断処理をルール化していく。例えば，“定速 モード”の中で“目標速度をやや超過し，しかもまだ 加速中であれば，ノッチを少し戻す。”という運転操 作があれば，これをルールの形で次のようにまとめる。

· IF（条件 A かつ条件 B) THEN（于順 A)

- 条件 A：速度が目標速度以上かつ日標速度十 $\mathrm{V}$ 以下である。

・条件 B：加速度が A $1 \leqq a<\mathrm{A} 2$ の範䎴にある。

・手順 $\mathrm{A}$ ：ノッチを $\mathrm{n}$ ステップ杘す。

判断操作が必要な制御条件はすべて洗い出し,ルー ル化する。通常の運転操作のみでなく, 考えうる異常 ケースも可能な限りルール化して抢く。例えば，“急 激な滅速度検知は滑走 (※6) 発生とみなし, ノッチ をやや戻す。”等である。これにより，通常は発生し ない大きな外乱（例えば，一瞬非常ブレーキ $(※ 7)$ が 動作）により，制御が乱された場合でも，あらかじめ 想定しておけば状況に応じた適切な回復操作を行うこ とができる。

\section{3 判断ロジック}

獲得されたルールは，走行モードごとに判断ロジッ クの形にまとめる。判断ロジックは, 制御条件の各要 素と制御手順との関係を論理記号によって示したもの で，ルールが客観的な戝形として表現される。論理記 号としては，積・和・否定・分配の四つの基本記号を 用いる。一つの走行モード内にあるすべてのルールは, 


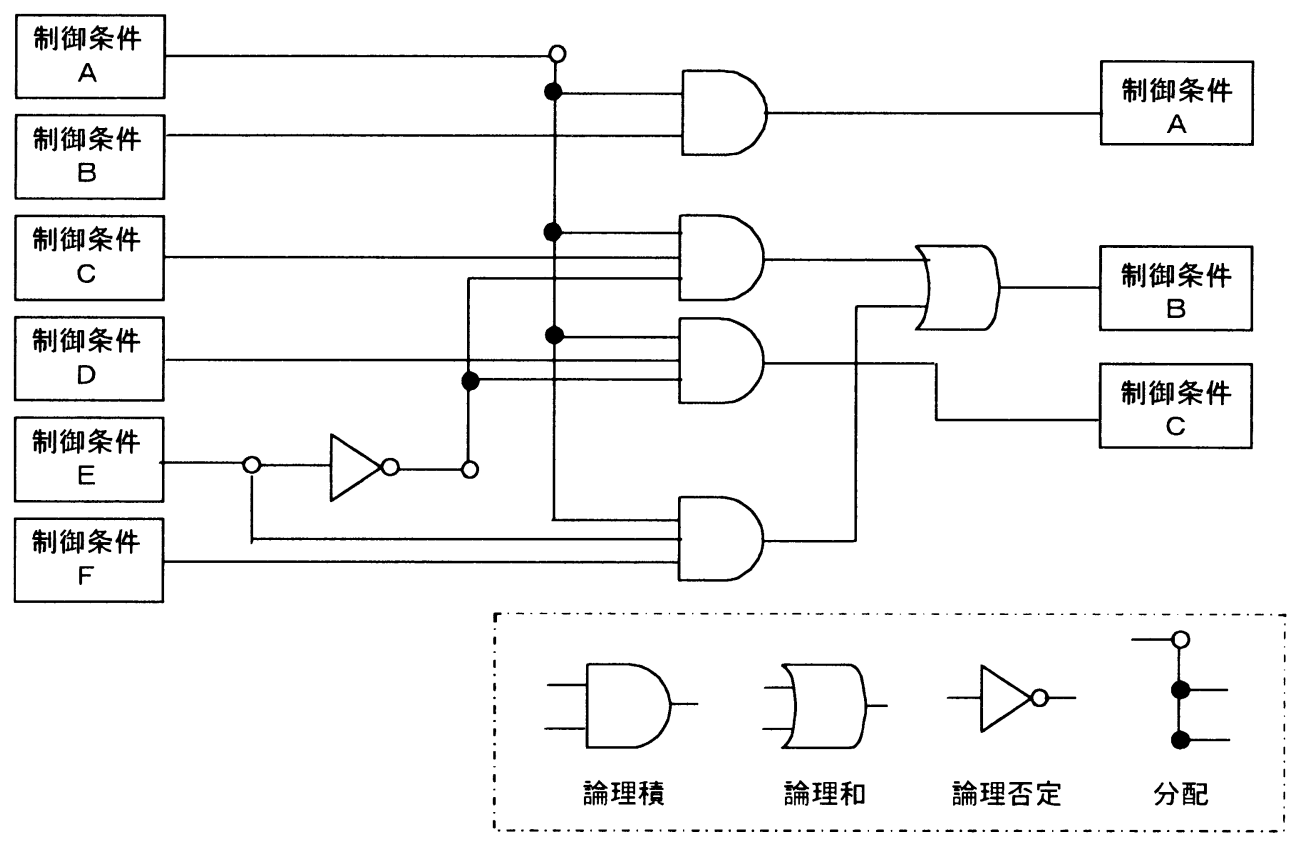

図 5 判断ロジックの例

一つの判断ロジックとしてまとめる。6.2 節の例では, 条件 $\mathrm{A}$ と条件 $\mathrm{B}$ が論理皘で結合され, 手順 $\mathrm{A}$ に接続 される。これを他のルールと組み合わせて判断ロジッ クにした例を図 5 に示す。间一走行モード内であれば 運転状況は似通っており, ルール間で条件項目及び手 順項目の内荇が共通に現れる場合がある。判断ロジッ ク上では, 间一項月は共通にまとめるため, 全体とし て無䭾のないコンパクト形になる。

判断ロジックができた段階で論理に矛盾や漏れがな いかを点検する。すべての制御条件に扔いて，一つの 走行モード内では，ただののの手順が選択されるか, いずれの师順も選扑されないかのどちらかであり，複 数の手順が间時に選択されることのないように論理を 点検する。术行モードごとにまとめられた判断ロジッ クが，知識データとして知識べ一スに記憶される。

\section{7. 自動運転エキスパートシステムの動作}

\section{1 エキスパートシステムの構成}

ATO 装置内で起行制御を実行する “自動運転エキ スバートシステム”部の機能ブロックを図 6 に示す。 全体は, 走行管理部とエキスパートシステム部（以下 “エキスパート部”という。）とに分かれる。走行管理 部は, 装置の外部環境とエキスパート部との間に位置 し，これらの境界を取り持つ。

走行管理部は外界の情報を入力し, エキスパート部

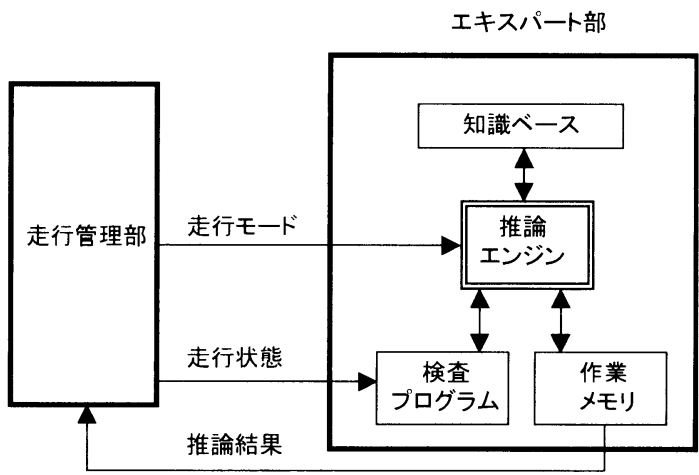

図 6 自動運転エキスパートシステム機能ブロック

が認識できる形に加工して渡す。また，走行管理部は 走行状態を常に監視しており, その時点での走行モー ド種別をエキスパート部に通知している。走行モード が遷移した段階で, 直ちに新たな走行モードをエキス パート部に通知する。エキスパート部は, 指定された 走行モード内の知識に基づいて推論を実行すればよい ので応答が速く, 実時間制御に十分対応することがで きる。エキスパート部は, 推論結果を制御手順として 走行管理部に通知する。走行管理部は, 指定された制 御手順を実行することで, 実際の走行制御出カが行わ れる。

エキスパート部は, 推論エンジン知識ベース, 検査 
プログラム, 作業メモリで構成される。推論エンジン が推論を実行する中心機能部である。知識ベースには， 走行モードごとの判断ロジックが記憶されている。推 論エンジンは, 列車の走行状態に基づき判断ロジック の内容を評価し, 結果を作業メモリに記憶する。判断 ロジックで規定される制御条件については，条件の判 定を検査プログラムを用いて行っている。検査プログ ラムは，走行管理部から実時問で列車の状態情報を入 力し, 指定された制御条件の判定を行う。例えば“列 車の減速度が $\mathrm{A} 1 \leqq \beta<\mathrm{A} 2$ の範囲にある。”とった 制御条件に対し，列車の実際の検知減速度を走行管理 部から取り出し，条件を満たせば“真”を，満たさな ければ“偽”を值として返す。作業メモリには，推論 の途中経過及び推論結果が記億される。したがって, 走行管理部は推論結果を作業メモリ経由で取り出す。

\section{2 推論の実行}

推論の実行は，判断ロジックを評価することで行わ れん判断ロジックは，スタート・論理積・和・否定・ 分配・ゴールの 6 つの要素からなる。スタートが個別 の制御条件要素に相当し，ゴールが制御手順に相当す る。推論の実行によってスタート要素から順に, ゴー ルに至るすべての要素が評価されていく。実際の推論 は，要素間の值の伝播という形で実行される。スター ト要素の值は，検查ブログラムにより与えられ，次の 接続要素に值を伝播する。值は，“真”か“偽”かの いずれかである。各要素は，入力端子に值が伝播され てくると論理演算を行い自身の值を得る。得た值は, さらに次に接続される要素に伝播される。值が常に先 に伝播していくことから，前向き推論といえる。走行 制御はは，その時点の状態に応じた実時聞制御であり， 高速応答が得られる前向き推論が適している。
判断ロジック上のすべての要素の值が確定した時が 推論の終了となる。1 回の推論に要する時間は $50 \mathrm{~ms}$ 以下であり，十分に実時間制御を実施することができ る。推論の成果は, 唯一真となったゴールによって制 御手順が決定することである。判断ロジックは唯一の ゴールだけが真となるように論理構成されており，真 となったゴールの制御手順が実䘕される。複数のゴー ルが真となることはないが，すべてのゴールが偽とな ることはある。この場合は，いずれの制御手順も実行 されず，結果としては前推論サイクルの制御状態が雑 持されることになる。

\section{3 走行制御の実施例}

走行間制御は，詳細なルールの組み合わせであり， これを端的に表現することは難しいが，定速走行区間 での制御例を図7に示す。

\section{8. システム導入の効果}

\section{1）駅間走行制御}

定位置停止制御（TASC）区聞では，四つの走行モ 一ドに分割し，モードごとにきめ練かな制御を行なっ たため，とかく相反する事項である乗り心地と停止精 度の向上が合わせて実現できた。また，急勾配での制 御もうまくこなしている。従来方式では，こうした最 急勾配に対応できるように調整すれば，通常区問では 制御ゲインが高すぎて乗り心地を害するといった結果 になりがちであった。また，外乱によって通常制御範 囲を外れた場合は，外れ方に合わせた制御手順を適用 しているため，異常時の回復機能が大幅に改善された。

定速走行区間では, 路線に応じた均衡ノッチの出力 が適切に行われるため，ノッチの変化が非常に少ない 走行が実現できた。

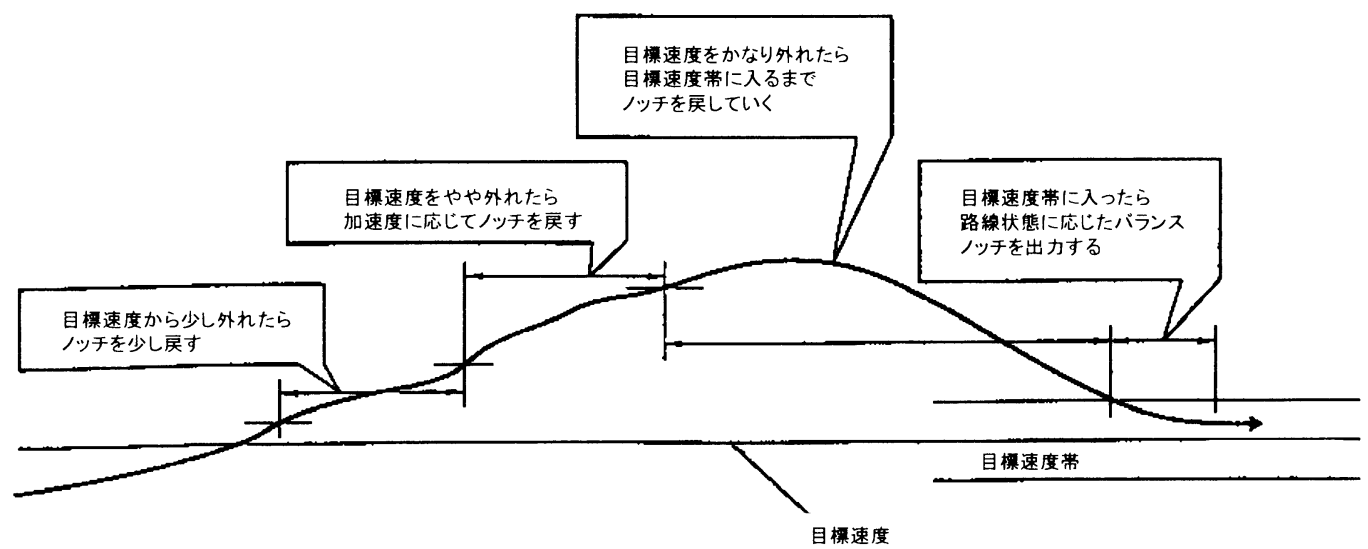

図 7 定速走行の制御例 


\section{2）試験調整期間の短縮}

以下に亦す効果により，現車での試験調整期間が短 縮できた。

・知識が客観的に表現されているため変更箇所を的 確に把握することができる。

・知織の変更はデータの変更となり, プログラム手 順に比べ，変更が容易であるばかりで なく，間 違いの入る余地が少ない。

・制御条件が限定されているため, 不具合部分のみ を独立して変更することができ，他の制御への副 作用が出ない。

\section{9.むすび}

以上, エキスバートシステムを適用したATO 装置 の概略を述べた。エキスパートシステムでは，制御知 識をいかに獲得するかがポイントとなる。はじめは, 運転を想定したシミュレーション，運転士の操作の観 察，などから蓄積するしかなかったが, 現在では, こ れまでのシステム開発で培ったノウハウを十分活用で
きるようになってきた。このため, 新規路線の開発に おいても，短期間でベテラン運転士に近い運転が実現 できるようになってきた。

(注)

$※ 1$ : Automatic Train Control（自動列車制御）

$※ 2$ : Train Automatic Stop Control（定位置停止制 御)

$※ 3$ : Automatic Train Control（自動列車制御） （制減速度を列車速度が超えた場合，ブレーキ を出力する)

※4：車両に加速トルクを与える指令（自動車のア クセルに相当する)

$※ 5$ : Master Controller

$※ 6$ ：車輪がロックし, 過大な減速度を検知する状 況

※7：緊急時に動作する空気ブレーキ

参考文献

三菱電機技報ＶOL. $64 \cdot$ No $10 \cdot 1990$ 